\author{
Jean Paul Kouega \\ University of Yaounde I, Cameroon \\ Mildred Aseh \\ University of Yaounde I, Cameroon
}

\title{
PIDGIN IN CREATIVE WORKS IN ENGLISH IN CAMEROON
}

Summary. This study, which deals with code-switching and language choice in multilingual contexts, describes the use of Pidgin in creative works in English in Cameroon, with the focus on the forms that this language takes in the works, the types of characters who are made to speak this language, and the functions that this language plays in these works. The data comprise three plays and two novels, all published between 2000 and 2006 by experienced writers who have a good command of English and yet make their characters speak in Pidgin. The analysis shows that Pidgin in the corpus takes the form of individual lexemes like salaka (libation, sacrifice) and relatively short utterances like This sun fit kill man (This sun is so hot that it can kill someone.). The characters who speak Pidgin in these literary works are generally low-ranking and rural people, illiterates and other people who are hardly looked up to in the Cameroonian society. Finally, Pidgin helps writers to realise some stylistic effects such as variations on the scale of formality, with English being used when addressing a superior person and Pidgin when addressing an inferior person. Most importantly, creative writers reproduce in their works what is observed in the Cameroonian society and this can be regarded as a formal way of enhancing their readers' plurilingual competence.

Keywords: Cameroon Pidgin English; creative works; code switching; attitude; language choice.

\section{Introduction}

In Cameroon, Pidgin is reported to be used in many domains of language use: home, neighbourhood, work place, school, religion, court, official correspondence, media and public places. Unfortunately, very little is known about how it is actually used in each domain. This study takes up one domain, i.e. the media, and focuses on one type of print media, i.e. creative writing. Although Pidgin is hardly used to produce creative works in Cameroon, this language does occur in creative writing in other languages, notably works in English and French. This study examines Pidgin in creative works in English in Cameroon. The questions underlying the investigation are:

- what form does Pidgin take in creative works in Cameroon? 
- which characters are made to speak Pidgin in the works?

- what functions does Pidgin play in the works?

The frame adopted for the research is an aspect of Gumperz's (1982) "contextualization cue" and of Myers-Scotton's (1993) markedness theory, this aspect being language choice in bilingual and multilingual contexts. Language choice is a feature that generally surfaces in studies of bilingualism and multilingualism; it refers to the factors which determine the choice of one language rather than the other(s) in the bilingual or multilingual speaker's language repertoire. Strangely enough, no specific frame for the description of this phenomenon has been developed. In his "contextualization cue", Gumperz observes that code-switching and code-mixing signal a change in topic, attitude, or interest since each one of the various languages within multilingual societies has its specific identity and function. In her markedness theory, Myers-Scotton examines the rationale behind interlocutors' linguistic choices. According to this theory, in any bilingual speech event, there are unmarked linguistic choices and marked choices. The unmarked linguistic choice is that which is accepted by the particular linguistic community as the norm in any given speech event. On the other hand, the marked linguistic choice is what is customarily regarded as unacceptable in any given speech event. In multilingual communities, the switched variety is the unmarked choice. The answers to the research questions outlined above will shed light on the overall attitude of Cameroonians to Pidgin. The work is divided into three sections titled background to the study, methodology, results and discussion. These are considered in turn.

\section{Background to the Study}

The language situation in Cameroon, the place of Pidgin in the country's linguistic landscape and creative works in English in this country are overviewed below. Cameroon is a country where some 20 million inhabitants speak several languages. First, over 250 different ancestral languages (Ethnologue, 2005; Kouega, 2007a; Lewis, Simons \& Fennig, 2014) are used by various communities in the country. Second, four major non-localised lingua francas, i.e. Beti, Camfranglais, Fulfulde, and Pidgin co-exist; they have in common that they 
straddle two or more of the ten regions of the country. Lastly, there are two imported languages that jointly serve official functions, i.e. French and English.

Fulfulde is dominant in three northern regions of Cameroon, i.e. Adamawa, North and Far North. It is the language of the Muslim Fulbes who conquered the northern half of Cameroon before colonisation. Originally, this territory was inhabited by various Sudanese communities. Then groups of Fulbe people, also known as Fulani, came from Senegal, passed through northern Nigeria and Cameroon and went as far as Chad and Sudan. Characteristically, they were Muslims on a crusade aimed at evangelising the Kirdis, or pagans. The first groups of Fulbe to arrive, though converted to Islam, were not strong believers in this religion. Their major occupation was animal husbandry, and they successfully integrated themselves among the Sudanese communities they met. The next groups of Fulbe immigrants came from Nigeria, purposely to teach the Koran and to convert, by will or by force, all pagans they encountered. They succeeded in conquering the whole of northern Cameroon, from Lake Chad to the Adamawa plateau, seizing all fertile lands, thus forcing non-believers (i.e. the Sudanese), to seek refuge in inaccessible high lands. The native speakers of Fulfulde are estimated at around 700,000 and the total number of its users within the country may be over five million out of the country's population of 15 million people in 2003. Speakers of its variants are found in the area stretching from Senegal through Cameroon to Sudan, and are estimated at around 13 million (Ethnologue, 2005). Ideally, one can operate in northern Cameroon (Far North, North, and Adamawa and even part of the north of the East region) with a rudimentary knowledge of Fulfulde. However, the language is associated in the minds of most people with Islam, since its speakers tend to be Muslims who occasionally use it to teach the Koran (Abdkrm, 2000).

Beti is spoken in the south of Cameroon (Centre and South regions as well as the southern part of the East region) and in the north of three neighbouring countries, i.e. Gabon, Equatorial Guinea and Congo. It is the group name of a cluster of mutually intelligible ancestral languages spoken in this region. These languages include Bebele, Bulu, Eton, Ewondo, Fang and Mangisa, to cite only the most dominant ones in Cameroon. Together, Beti speakers, found in Cameroon in the forest zone in the southern half of the country, are estimated at around two million (Ethnologue, 2005). Second language users of Beti, who are 
mainly immigrants who reside in - or people who usually visit - the East and South regions, speak a simplified variety of the language commonly referred to as Petite Ewondo or Mongo Ewondo (Koenig, 1983). Although the languages of this group share a high proportion of linguistic features, their speakers view themselves as sharing a common culture but not a common language. This may be one of the reasons why Ethnologue (2005) regards these languages as separate entities rather than dialects of the same language, as Dieu and Renaud (1983) did.

Camfranglais is a language variety spoken throughout the national territory by most educated youths who have attained secondary education. It is a created mixed language variety whose syntax follows the French language pattern and whose lexical elements are drawn from French, English, Pidgin and other widespread languages in Cameroon. Consider, for example, the following speaking turn extracted from a conversation:

Moi, je ne lap pas avec lui, mais il est came me tell son anniv.

[Me, I not laugh - with him, but he came me tell his birthday]

(Me, I do not chat with him, but he came to tell me about his birthday.)

In this utterance, the English lexical words lap (from "to laugh"), came (from "to come"), and tell ("to tell") are inserted into a French-based structure.

Functionally, Camfranglais resembles a slang, which youngsters use to communicate among themselves to the exclusion of non-group members. Fluent users are secondary school students, who eventually leave school and become soldiers and policemen, thieves and prisoners, gamblers and conmen, musicians and comedians, prostitutes and vagabonds, hair stylists and barbers, peddlers and labourers and, in a few cases, high-ranking civil servants and businessmen. This language form seems to be preferred by youngsters when they discuss issues of importance to them such as food and drink, money, sex, physical appearance, states of mind, reference to kin and other people, to name only a few domains. A look at its origin shows that it emerged in the early eighties, when the decision to promote bilingualism in education by teaching English as a subject in French-medium secondary schools in the country was fully 
Jean Paul KOUEGA, Mildred ASEH

implemented, as a later section below will show. Various aspects of this language variety have been examined in the last three decades by such researchers as Ze Amvela (1989), Biloa (1999, 2003), Echu (2001), Kouega (2003a, 2003b, 2013). These studies clearly show that this language form is a variant of Cameroon French.

Pidgin is spoken mainly in the two Anglophone regions of Cameroon and the two francophone regions adjacent to these ones, i.e. Littoral and West regions. Elsewhere other languages of wider communication are dominant. Ethnologue (2005) estimated the number of its speakers, who are mainly second language users, to be around two million people when the country's population was around 15 million. According to some researchers (e.g. Todd \& Hancock, 1986 , p. 90), it is spoken by ' $50 \%$ of the population' and it is 'becoming a mother tongue in some urban communities'. In a study carried out in 1983, Mbangwana found that this language was different from the others spoken in the country in that it was a 'non-ethnic language'; besides, it was spoken throughout the country for out-group communication between people of all levels. Mbangwana also observed that Pidgin was used in the media especially in advertisements, in music production among stars such as Nico Barga (a very popular musician in the 1970s), in political rallies especially in the two anglophone regions and the two neighbouring Francophone regions. It was said to be the language of religion as well as the commonest code for buying and selling and for story-telling. In a more recent study, Kouega (2001) found that Pidgin was spoken by educated people in various settings: in the home with their household helps, in the neighbourhood in interactions with friends, neighbours and traders and in the work place, especially when giving instructions to subordinates or interacting with equals. Today, it is used in the spoken media, especially radio stations such as Mount Cameroon in Buea, Radio Siantou in Yaounde, FM 105 in Douala, the Northwest Regional radio station (CRTV) in Bamenda.

Some researchers have attempted to examine the relationship that exists between Pidgin and the other languages spoken in the country. To Dieu and Renaud (1983), Pidgin does not belong to any of the language families identified in Cameroon. As Ethnologue (2005) points out, it does not have adult mother tongue speakers, although a few cases of young L1 speakers are occasionally 
found in the country, especially in mixed marriage homes. Just as the various languages spoken in Cameroon have affected Pidgin - as will be shown later - so too has Pidgin affected Cameroon languages. Actually, Pidgin has been the main lexifier of the indigenous languages spoken in the southern half of the country. During the years 1885-1915 when the Germans settled in Cameroon, Pidgin was already a fully-grown language, and it was used in interactions between the colonizers and the indigenes. The Germans had to construct roads, railways and bridges to cart away agricultural and mining products. To carry out these development projects, the German administrators needed large numbers of labourers, who were available in the hinterland. These labourers, who spoke different indigenous languages, were forced to live together. As the only outgroup language available was Pidgin, the labourers picked it up, thus increasing the number of its speakers. When these unpaid labourers managed to escape, they took the Pidgin words they had acquired to their hometowns. When the Germans finally left the country after the First World War, most labourers went back to their hometowns, taking along the Pidgin words they had been using. Today Pidgin is the main lexifier of most Cameroonian languages spoken in both anglophone Cameroon and the southern half of francophone Cameroon. The Cameroonian languages for which some information on how they were affected by Pidgin is available include, among others, Bakweri (Todd, 1982, p. 89), Shu Pemem (Njoya, 1988), Medumba (Kachin, 1990), Ewondo, i.e. Beti (Fouda, 1991) and Ngyemboong (Fasse-Mbouya, 2000).

Creative works in English in Cameroon fall into the three common literature genres, i.e. poetry, drama and prose. Poetry, the least popular of these three, is the genre chosen by writers like Atemkeng Achanga ("Heart to heart", 1982), Mbella Sonne Dipoko ("Black and White in love", 1972) and Mesack Takere ("Kingfisher poetry: The tortoise", 1983). Drama made some writers famous, like: Bate Besong ("Beasts of no nation", 1990), Bole Butake ("Lake God", 1986), Sankie Maimo ("Succession in Sarkov", 1986). Prose is by far the mode of expression most frequently chosen by writers, including: Asong Linus ("The crown of thorns", 1990), Nsanda Eba ("The good foot", 1977), Kenjo Jumban ("The whiteman of God", 1980), Ngongwikuo ("Taboo love", 1980). Examining some 27 Cameroonian novels in English, Ambanassom (2007) observed they can be grouped on the basis of the "what" and "how" of each novel, into five classes, 
Jean Paul KOUEGA, Mildred ASEH

which he labelled as follows: encounter with Europe (Kenjo Jumban, "The White man of God", 1980), anti-heroes and societal crooks (Linus Asong, "No way to die", 1991), women and sexuality (Mbella Sonne Dipoko, "A few nights and days", 1966), opposing visions of feminism (Margaret Afuh, "Born before her time", 2003) and, lastly, alternative ideological visions (Alobwed'Epie, "The death certificate", 2004). The present study examines the use of Pidgin in a sample of literary works.

\section{Methodology}

This section describes the period of the study, the informants, the material collected and the method of data analysis. The period of the study was the years 2000-2006, which is when the attitude of Cameroonians to Pidgin was first expressed in quantifiable terms (Kouega, 2001). It was felt that creative works published around that period will support these findings. The creative works of that period were published by: Anne Tanyi-Tang, Bate Besong, Bole Butake, Charles Alobwed'Epie, John Nkemngong Nkengasong. These are seasoned university lecturers who are at the same time, creative writers. As has been proven elsewhere, they are competent English users and fluent Pidgin speakers who know how to keep the two languages apart. These writers make their characters (old men and women, friends, boys and girls, village dwellers to name only these) speak Pidgin. These characters are the real informants of this study but since they cannot be described, the profile of the writers who created them is provided here.

Anne Tanyi-Tang is a playwright and a producer and play director. She obtained a Bachelor of Arts (BA) in English at the University of Yaounde, Cameroon in 1985. Then in 1987, she enrolled in the Department of Drama and Theatre Studies, Faculty of Humanities University of Kent at Canterbury, England, where she obtained a Master of Arts (MA). Later on, in 1994, she enrolled in the Department of Social Anthropology, Faculty of Arts, University of St. Andrews, Scotland, where she obtained the degree of Doctor of Philosophy (PhD) in Drama, Theatre and Social Anthropology in July 1994. Bate Besong was educated in St. Bede's College Ashing, Hope Waddell Institute Calabar, the University of Ibadan and at the University of Calabar. His works include Requiem for the last 
Kaiser (1991), The Banquet (1994) and Just above Cameroon (1998). He was the winner of the 1992 ANA Literature Drama Prize.

Bole Butake is a writer, critic and theatre director and has organised workshops throughout the country on various issues using the technique of Theatre for Development. He was born in Nkor, Noni Subdivision in the NorthWest Region of Cameroon. His major publications include Lake God (1986), And Palm-wine Will Flow (1990), Zintgraff and the Battle of Mankon (2002) and Family Saga (2005). Charles Alobwed'Epie is a poet, novelist and critic. He studied at the Universities of Yaounde and Leeds. He attained the grade of Associate Professor at the University of Yaounde I, Cameroon. His major works include The Death Certificate (2004), The Day God Blinked (2008), The Bad Samaritan (2009), and The Lady with the Sting (2010). John Nkemngong Nkengasong is a Cameroonian poet, playwright, novelist and critic. He was educated at the University of Yaounde 1 where he obtained a PhD. His major publications include Black Caps and Red Feathers (2001), W. B. Yeats and T.S Eliot: Myths and Poetics of Modernism (2005), Letters to Marion and several scholarly essays published in national and international journals. He has been a Fulbright scholar at New York University, guest writer at the University of Oxford, visiting academic at the University of Ragenburg, Germany and recently a participant in the International Writing Program at the University of Iowa, USA.

The corpus collected comprises three plays and two novels. The plays are: "Beasts of no nation", "Betrothal without libation" and "My bundle of joy" and the novels are "The lady with the beard" and "The widow's might". Bate Besong's "Beasts of no nation" is a piece of drama published in 2003. It is a sixty-one-page play made up of three parts, labelled: The Parabasis, Beasts of no Nation and Aadingingin, and the Night-Soil-Men. Bole Butake's "Betrothal without libation" was published in 2005. It is a seventy-six-page play made up of three Acts with Act One having five scenes and Acts Two and Three having four scenes each. Anne Tanyi-Tang's "My bundle of joy" was published in 2000. It is a twenty-threepage play made up of Two Acts with Act 1 having eleven scenes and Act 2 seven scenes. "The widow's might", a novel published in 2006 by John Nkemngong Nkengasong, is a 152-page book divided into of eight chapters. Alowbwed'Epie's "The lady with a beard" which was published in 2005, is a 118-page novel made up of eighteen chapters. 
Jean Paul KOUEGA, Mildred ASEH

Regarding the method of data analysis, these works were first read and instances of Pidgin were identified and classified into ordinary words or lexemes and sentences or utterances. Then the works were read again with the focus this time on the indexical features of the characters who switched to Pidgin, and the reason why the writers made these characters switch to Pidgin.

\section{Results and Discussion}

The analysis is divided into three sections. The first section focuses on the linguistic form that Pidgin takes in the corpus. The second section deals with the characters who are made to speak Pidgin by creative writers and the third section considers the social factors underlying the choice of Pidgin in the corpus. These are considered in turn.

\section{Linguistic Forms of Pidgin in the Corpus}

Items drawn from Pidgin in the corpus take two broad linguistic forms; they are generally lexemes and utterances.

\section{Lexemes}

Pidgin lexemes are occasionally inserted in creative writing in English in Cameroon. These lexemes may be direct loans or cases of loan translation. Direct loans are considered first.

Take the following extract where the loan words $\mathrm{Pa}$, nyongo and mama are used. Note that italics are used here to highlight these words.

Wase: Pa Bonjo (Njanji's paternal uncle) was killed by villagers who claimed that he sold Njanji to nyongo. Kechen: It's unthinkable. Mum, does nyongo exist?

Wase: I can't say precisely. People have talked about it until I have started believing that it exists.

Kechen: What a world!

Wase: I wished you were there. It was such a pity.

Ketchen: I am sorry, very sorry indeed.

Wase: You see, I don't want you to come to the village. 
Kechen: But mama, why must you insist on returning to the village? You may die just like Njanji.

Wase: I will die when God calls.

Kechen: (Silence) Mama, I am sorry. Perhaps, if I had children you would have stayed to look after them.

(Tanyi-Tang 2000, pp. 44-45)

In this text, the word Pa can be replaced by "mister", nyongo by "witchcraft" and mama by "mummy"; however, the use of their standard equivalents would not have had the same stylistic effects as the direct loans.

Another set of illustrations is found in the extract below from Nkengasong (2006, p. 134), where makara, buyam-sellam and okrika are used:

She thought of becoming a Born-Again Christian; she thought of starting a small makara business, she thought of returning to town after the burial, borrowing money and starting a chicken parlour business. But she hated any thing that would bring her very close to men. A hatred for men made her mind sour. She thought of becoming a buyam-sellam; of trading in okrika, of going back to school. She almost laughed at the thought of the last alternative. She sighed, shook her head and continued to watch people view the corpse and depart.

In the five-work corpus under study, some 26 direct loans are identified and they are found to occur 204 times, as Table 1 below shows.

Table 1.

Direct loans in the corpus

\begin{tabular}{|c|c|c|c|c|c|c|}
\hline \multirow{2}{*}{$\begin{array}{c}\text { CPE } \\
\text { words }\end{array}$} & \multicolumn{5}{|c|}{ Number of instances in the corpus } & \multirow[t]{2}{*}{ Total } \\
\hline & $\begin{array}{c}\text { The } \\
\text { widow's } \\
\text { might }\end{array}$ & $\begin{array}{c}\text { Betrothal } \\
\text { without } \\
\text { libation }\end{array}$ & $\begin{array}{c}\text { The lady } \\
\text { with a } \\
\text { beard }\end{array}$ & $\begin{array}{c}\text { My } \\
\text { bundle } \\
\text { of joy }\end{array}$ & $\begin{array}{c}\text { Beasts } \\
\text { of no } \\
\text { nation }\end{array}$ & \\
\hline agbada & 2 & - & - & - & - & 2 \\
\hline Akwara & 2 & - & - & - & - & 2 \\
\hline Ashawo & 1 & - & - & - & - & 1 \\
\hline Ashia & 1 & - & - & - & - & 1 \\
\hline Ashuobi & 2 & - & - & - & - & 2 \\
\hline Bamis & 4 & - & - & - & - & 4 \\
\hline Bonga & 1 & - & - & - & - & 1 \\
\hline $\begin{array}{l}\text { buyam- } \\
\text { sellam }\end{array}$ & 1 & - & - & - & - & 1 \\
\hline $\begin{array}{l}\text { come- } \\
\text { no-go }\end{array}$ & 2 & - & - & - & - & 2 \\
\hline Garri & 1 & - & - & - & - & 1 \\
\hline Graffis & 4 & 1 & - & - & - & 5 \\
\hline Juju & 1 & 1 & - & - & - & 2 \\
\hline
\end{tabular}


Jean Paul KOUEGA, Mildred ASEH

\begin{tabular}{|c|c|c|c|c|c|c|}
\hline \multirow{2}{*}{$\begin{array}{c}\text { CPE } \\
\text { words }\end{array}$} & \multicolumn{5}{|c|}{ Number of instances in the corpus } & \multirow[t]{2}{*}{ Total } \\
\hline & $\begin{array}{c}\text { The } \\
\text { widow's } \\
\text { might }\end{array}$ & $\begin{array}{l}\text { Betrothal } \\
\text { without } \\
\text { libation }\end{array}$ & $\begin{array}{c}\text { The lady } \\
\text { with a } \\
\text { beard }\end{array}$ & $\begin{array}{c}\text { My } \\
\text { bundle } \\
\text { of joy }\end{array}$ & $\begin{array}{l}\text { Beasts } \\
\text { of no } \\
\text { nation }\end{array}$ & \\
\hline $\mathrm{Ma}$ & 112 & 3 & - & - & - & 115 \\
\hline makara & 1 & - & - & - & - & 1 \\
\hline Mama & 3 & 3 & 2 & 8 & - & 16 \\
\hline Mami & 4 & - & 1 & 1 & - & 6 \\
\hline Muyo & - & - & 7 & - & - & 7 \\
\hline ngrimba & 2 & - & - & - & - & 2 \\
\hline Njangi & 1 & - & - & - & - & 1 \\
\hline Nyango & 1 & - & 2 & - & - & 3 \\
\hline Nyongo & - & - & - & 2 & - & 2 \\
\hline Okrika & 1 & - & - & - & - & 1 \\
\hline Okro & 1 & - & - & - & - & 1 \\
\hline $\mathrm{Pa}$ & 5 & 3 & - & 1 & - & 9 \\
\hline Papa & 6 & - & - & - & - & 6 \\
\hline Potopoto & 3 & - & - & - & - & 3 \\
\hline Sah & - & 3 & - & - & 3 & 6 \\
\hline Salaka & 1 & - & - & - & - & 1 \\
\hline Total & 163 & 14 & 12 & 12 & 3 & 204 \\
\hline & $79.9 \%$ & $6.86 \%$ & $5.88 \%$ & $5.88 \%$ & $1.47 \%$ & $100 \%$ \\
\hline
\end{tabular}

The bulk of these loans (79.9\% of 204 occurrences) is found in Nkengasong's "The widow's might", a 152-page novel. The main characters of this eight-chapter novel are:

Honourable Makata Mbutuku: Member of Parliament for the town of Bakomba

Akwenoh (Mami Makata): Honourable Mbutuku's wife

Ma Eseke: Honourable Mbutuku's sister

Chief Ekwe: Honourable Mbutuku's brother

Emade: Akwenoh's friend

Mama: Akwenoh's mother

Madam Opote: Widow of a former parliamentarian

Honourable Malingo: The parliamentary group leader

The novel begins with Honourable Makata Mbutuku returning home late with good news: he was consulted for an appointment to a ministerial post. He shared the good news with his wife who was very happy and started pondering over how she would be behaving when she becomes a minister's wife. Unfortunately, that very night, Honourable Mbutuku kicked the bucket. From the characters and the story line of the novel, there is no justification for the high proportion of occurrence of Pidgin loans in this work.

In the list above, two words seem to stand out; these are $M a$, which is used 115 times out of 204 occurrences of loans in the corpus, i.e. $57.21 \%$ and mama which is used in four of the five-work corpus. These two words mean 
"mummy" or "mother". In Table 2, these 26 loans are listed in the corpus and their meanings as outlined in the dictionary of Cameroon Pidgin English (Kouega 2008, 2015):

Table 2.

\section{Meaning of loan words in the corpus}

\begin{tabular}{|c|c|c|}
\hline $\begin{array}{l}\text { Spelling } \\
\text { in the } \\
\text { corpus }\end{array}$ & $\begin{array}{l}\text { Spelling in } \\
\text { the } \\
\text { dictionary }\end{array}$ & Meaning \\
\hline Agbada & abada & $\begin{array}{l}\text { a type of gown usually worn by people from the northern } \\
\text { provinces (of Cameroon) }\end{array}$ \\
\hline Akwara & akwara & a prostitute \\
\hline Ashawo & ashawo & a prostitute \\
\hline Ashia & ashia & $\begin{array}{l}\text { a term performing at least three communicative functions: } \\
1 \text {. A universal expression of greeting; } 2 \text {. expression of } \\
\text { compassion addressed to someone who is, say, in pains; } 3 \text {. } \\
\text { expression of gut and defiance }\end{array}$ \\
\hline Ashuobi & ashwabi & A uniform for a ceremony \\
\hline Bamis & Bami & short for Bamileke, one of the major tribes in Cameroon \\
\hline Bonga & $\begin{array}{l}\text { bonga, buga } \\
\text { or mbonga }\end{array}$ & dried herring, smoked fish \\
\hline $\begin{array}{l}\text { buyam- } \\
\text { sellam }\end{array}$ & bayam selam & 1. a retailer of food crops, 2 . to retail food crops \\
\hline $\begin{array}{l}\text { come- } \\
\text { no-go }\end{array}$ & kam-no-go & $\begin{array}{l}\text { 1. a type of skin disease that causes the body to itch and } \\
\text { does not respond to common drugs; } 2 \text {. a tribalistic label } \\
\text { used by politicians to describe Cameroonians living in the } \\
\text { Southwest province who are not native to the area; } \\
\text { settlement in a place. } 3 \text {. to go native, to settle in a place }\end{array}$ \\
\hline Garri & gari & $\begin{array}{l}\text { flour or powder obtained by grating cassava tubers and } \\
\text { then frying the resulting paste }\end{array}$ \\
\hline Graffis & Grafi & $\begin{array}{l}\text { an indigene of the Grass fields or Bamileke tribes of } \\
\text { Cameroon }\end{array}$ \\
\hline Juju & juju & 1. medicine man, witch-doctor; 2. something frightful \\
\hline Ma & $\mathrm{Ma}$ & $\begin{array}{l}\text { a polite form used in addressing a woman to whom one } \\
\text { wishes to show respect e.g. Ma Regina }\end{array}$ \\
\hline makara & akara & $\begin{array}{l}\text { (contracted form "akra"; plural: "makara"; plural } \\
\text { contracted: "makra") small fried balls made out of a special } \\
\text { variety of beans }\end{array}$ \\
\hline Mama & Mama & Mother \\
\hline Mami & Mami & Mother \\
\hline Mua & mua & to add, raise \\
\hline Muyo & moyo & $\begin{array}{l}\text { 1. an in-law 2. any member of the in-law family, both male } \\
\text { and female }\end{array}$ \\
\hline ngrimba & grimba & Witchcraft \\
\hline Njangi & njangi & (money obtained from) a traditional loan system \\
\hline Nyango & niango & a beautiful girl \\
\hline Nyongo & niongo & Witchcraft, evil sect or society \\
\hline Okrika & okrika & second hand clothes imported from Europe and sold in flea \\
\hline
\end{tabular}




\begin{tabular}{|l|l|l|}
\hline $\begin{array}{c}\text { Spelling } \\
\text { in the } \\
\text { corpus }\end{array}$ & $\begin{array}{c}\text { Spelling in } \\
\text { the } \\
\text { dictionary }\end{array}$ & markets \\
\hline Okro & okro & Okra \\
\hline $\mathrm{Pa}$ & $\mathrm{Pa}$ & $\begin{array}{l}\text { a polite form used in addressing a man to whom one wishes } \\
\text { to show respect e.g. Pa Atabong }\end{array}$ \\
\hline Papa & Papa & Father \\
\hline Potopoto & potopoto & mud, mud house, muddy road \\
\hline Sah & Sa & Sir \\
\hline Salaka & saraka & libation, sacrifice \\
\hline
\end{tabular}

Regarding cases of loan translation, these are Pidgin words or expressions which are translated into English. An example is book people:

Is that true? And she is your wife? Stop deceiving me. You book people are very daring. (Bole Butake, 2005, p. 35)

In this extract, "book people" is a translation into English of the Pidgin compound "buk pipu" which means "people who are educated". Here is another illustration:

I shall bear no person a grudge. But let me tell you mother-ofthe-sugarcane-grove, if a rat mole returns from an expedition and meets a new clearing at the entrance of its burrow and does not move house immediately, it becomes the broth of the next day meal. I shall move Ntube immediately. I shall send her to the Mission to live with teacher George and his wife. During the wedding, they asked me to allow her be their house-girl. (Alobwed'Epie 2005, p. 103)

The word "house-girl" here is the rendering in English of the Pidgin word "has gel" i.e. a "house help".

In the corpus, some nine instances are found (Table 3), the bulk of which are in Bole Butake's Betrothal without libation:

Table 3.

Loan translation terms in the corpus

\begin{tabular}{|l|l|l|l|l|l|c|}
\hline CPE words & \multicolumn{4}{l|}{ Number of instances in the data } & Total \\
\cline { 2 - 7 } & $\begin{array}{l}\text { The } \\
\text { widow's } \\
\text { might }\end{array}$ & $\begin{array}{l}\text { Betrothal } \\
\text { without } \\
\text { libation }\end{array}$ & $\begin{array}{l}\text { The lady } \\
\text { with a } \\
\text { beard }\end{array}$ & $\begin{array}{l}\text { My } \\
\text { bundle } \\
\text { of joy }\end{array}$ & $\begin{array}{l}\text { Beasts } \\
\text { of nation } \\
\text { nat non }\end{array}$ & \\
\hline book & - & 1 & - & - & - & 1 \\
\hline
\end{tabular}


PIDGIN IN CREATIVE WORKS IN ENGLISH IN CAMEROON

\begin{tabular}{|c|c|c|c|c|c|c|}
\hline \multirow[t]{2}{*}{ CPE words } & \multicolumn{5}{|c|}{ Number of instances in the data } & \multirow[t]{2}{*}{ Total } \\
\hline & $\begin{array}{l}\text { The } \\
\text { widow's } \\
\text { might }\end{array}$ & $\begin{array}{l}\text { Betrothal } \\
\text { without } \\
\text { libation }\end{array}$ & $\begin{array}{l}\text { The lady } \\
\text { with a } \\
\text { beard }\end{array}$ & $\begin{array}{l}\text { My } \\
\text { bundle } \\
\text { of joy }\end{array}$ & $\begin{array}{l}\text { Beasts } \\
\text { of no } \\
\text { nation }\end{array}$ & \\
\hline book people & - & 2 & - & - & - & 2 \\
\hline country talk & - & 1 & - & - & - & 1 \\
\hline cut corners & 1 & - & - & - & - & 1 \\
\hline direct follower & - & - & 1 & - & - & 1 \\
\hline house girl & - & - & 1 & - & - & 1 \\
\hline medicine-pot & - & 1 & - & - & - & 1 \\
\hline small man & 1 & - & - & - & - & 1 \\
\hline \multirow[t]{2}{*}{ Total } & 2 & 5 & 2 & - & - & 9 \\
\hline & 22.2 & 55.5 & 22.2 & - & - & $100 \%$ \\
\hline
\end{tabular}

These nine words express various meanings, as shown in Table 4:

Table 4.

Meaning of loan translation terms in the corpus

\begin{tabular}{|l|l|l|}
\hline \multicolumn{1}{|c|}{$\begin{array}{c}\text { Spelling in } \\
\text { the corpus }\end{array}$} & $\begin{array}{c}\text { Spelling in the } \\
\text { dictionary }\end{array}$ & Meaning \\
\hline book & Buk & a book, note \\
\hline book people & buk pipu & educated people \\
\hline country talk & kontri tok & an indigenous language \\
\hline cut corners & & $\begin{array}{l}\text { of a woman, to develop a flirtatious behaviour } \\
\text { (this word failed the tests for integration into } \\
\text { both Cameroon English - Kouega, 2007 - and } \\
\text { Cameroon Pidgin - Kouega, 2008) }\end{array}$ \\
\hline direct follower & darek folowa & $\begin{array}{l}\text { in a family, a child that comes next to another } \\
\text { child with no other child in between i.e. a junior } \\
\text { brother or sister }\end{array}$ \\
\hline house girl & has gel & a house maid, a house help \\
\hline medicine-pot & merisin, pot & $\begin{array}{l}\text { a pot said to be used to make charm (it does } \\
\text { not occur as a compound word) }\end{array}$ \\
\hline small man & smol man & a poor man \\
\hline
\end{tabular}

It should be noted that some of these words, which are good cases of lexical interference, have entered Cameroon English (Kouega, 2007).

\section{Utterances}

By utterance here is meant what a given speaker says during his or her turn of speaking in a conversation. In the corpus, utterances in Pidgin take two forms: bilingual dialogue and direct speech. 
Bilingual dialogue, a term coined by Ze Amvela (1989), is a kind of codeswitching in which one speaker uses one language when addressing some speakers and another language when addressing other speakers in the same conversation. Take for example this extract from Bole Butake (2005, p. 23), where four characters are conversing; these are: Tita, one of Paulina's customers, Paulina, a strong traditional liquor bar owner, Fointam, a final year student in a High Institute of education and Sama, a friend and classmate of Fointam:

Tita: Pass ma two bottles for here.

Paulina: Two bottro?

Tita: Yes, two. And bringam quick. This sun fit kill man.

Fointam: Sama, do you want another bottle?

Sama: Sure, Fointam, sure. The wine is first class. When I taste this kind of wine I never want to stop.

Fointam: Paulina?

Paulina: Sah?

Fointam: Four bottles-eh?

Paulina: Yes sah.

As can be seen, Tita and Paulina interact in Pidgin and so do Fointam and Paulina while Foimtam and Sama interact in English.

Here is another illustration where Kechen, Mallam and Boy are interacting. Kechen is McOkete's wife, Mallam is a herbalist and Boy is Mallam's servant:

Boy: (touching Ketchen) Madam, masa sey make you wait small. Kechen: Okay. Thank you. (to herself). If the renowned gynaecologist had succeeded, I would not have been sitting here and listening to "madam, masa sey make you wait small".

Mallam: (to boy) Tell madam Kechen make ee come inside.

Boy: Madam, mallam sey make you come inside. No forget for remove your shoes.

Kechen: I don hear. Thank you.

Mallam: Madam. I think sey you don forget we. Wuna dey fine?

Kechen: Yes, but...

Mallam: I know. I bee tell you say make you come back. But you nobi come. So I be thinks

sey all thing fine. Wait make I finam. (Throws cowries on the floor and examines

them very carefully. Turning to Kechen). Madam, your papa ye people dem dee vex 
with you for sika sey since you married, your masa no di give them money. (Examines

the cowries a second time). Dey wan one swine, one bag rice, mukanjo, salt and

tobacco. No forget strong mimbo. Tell ya masa. After you give dem all these things,

come back for me and I go give you medicine. After three months, you go carry bele.

My fee na only one thousand francs.

Kechen: So na so ngambe talk?

Mallam: (Irritated). Na so ngambe talk. Last time I ask dee ask me whether na so ngambe

talk. I no think seyyou wan carry bele .

Kechen: Mallam no vex. I just ask. I go do as you tell me. (Opens her handbag and hands over next month.

a note of one thousand frs to Mallam). Okay I go see you

Mallam: Madam waka fine. God go help.

Kechen: Thank you.(Exits. To herself.) How many times must I placate my father's relations?

I will do as mallam says. But I will not tell McOkete. He does not believe in

traditional doctors. I will tell him that I want to visit my grandmother. He will accept.

(Tanyi-Tang, 2000, pp. 46-47).

Kechen speaks to herself in English and to the other two interlocutors in Pidgin. In the corpus, six instances are identified (see Table 5), with five occurring in Bole Butake's play "Betrothal without libation".

Table 5.

Instances of bilingual dialogue in the corpus

\begin{tabular}{|l|c|c|c|c|c|c|}
\hline $\begin{array}{l}\text { Title of } \\
\text { books }\end{array}$ & $\begin{array}{l}\text { The } \\
\text { widow's } \\
\text { might }\end{array}$ & $\begin{array}{l}\text { Betrothal } \\
\text { without } \\
\text { libation }\end{array}$ & $\begin{array}{l}\text { The lady } \\
\text { with the } \\
\text { beard }\end{array}$ & $\begin{array}{l}\text { My } \\
\text { bundle } \\
\text { of joy }\end{array}$ & $\begin{array}{l}\text { Beasts of } \\
\text { no nation }\end{array}$ & Total \\
\hline $\begin{array}{l}\text { Occurrences } \\
\text { of bilingual } \\
\text { dialogue }\end{array}$ & - & 5 & - & 1 & - & 6 \\
\hline$\%$ & - & $83.3 \%$ & - & $16.6 \%$ & - & $100 \%$ \\
\hline
\end{tabular}

Direct speech, on the other hand, refers to the quoting of a speaker's words exactly as they were said. Graphologically, these words are placed within quotation marks. Here is an example: 
Jean Paul KOUEGA, Mildred ASEH

Presently Ntube saw a woman in over flowing Igbo gowns dragging two huge bags towards the hut. "My pikin, com helep me," the stranger entreated. Ntube ran to her and helped tug one of the bags into the hut. (Alobwed'Epie, 2005, p. 32)

Another example drawn from "The widow's might" runs thus:

"Na dem government no de fix road." He said. "dem don chop all money for country, but dem no de member say dem go waka for road time whe dem go die." (Nkengasong, 2006, p. 146)

In the corpus, some eight cases are identified (see Table 6), with five of them occurring in Alobwed'Epie's "The lady with the beard".

Table 6.

Instances of direct speech in the corpus

\begin{tabular}{|l|c|c|c|l|c|c|}
\hline Books & $\begin{array}{l}\text { The } \\
\text { widow's } \\
\text { might }\end{array}$ & $\begin{array}{l}\text { Betrothal } \\
\text { without } \\
\text { libation }\end{array}$ & $\begin{array}{l}\text { The lady } \\
\text { with the } \\
\text { beard }\end{array}$ & $\begin{array}{l}\text { My } \\
\text { bundle } \\
\text { of joy }\end{array}$ & $\begin{array}{l}\text { Beasts } \\
\text { of no } \\
\text { nation }\end{array}$ & Total \\
\hline $\begin{array}{l}\text { Occurrences } \\
\text { of direct } \\
\text { speech }\end{array}$ & 2 & 1 & 5 & - & - & 8 \\
\hline$\%$ & $25 \%$ & $12.5 \%$ & $62.5 \%$ & - & - & $100 \%$ \\
\hline
\end{tabular}

In short, when Pidgin is used in the corpus, it takes the form of an ordinary lexeme or an utterance. This finding answers the first question underlying this investigation.

\section{Characters speaking Pidgin in the corpus}

The characters who are made to speak Pidgin in the corpus and those who are referred to in Pidgin terms fall into various categories. In "My bundle of joy", Kechen, an educated housewife, addresses Wase, her mother-in-law, in Pidgin; she does the same when speaking with Mallam, a herbalist and Boy, the herbalist's assistant. Besides, she sings Pidgin songs when she is happy. In "The widow's might", the writer gives one of his characters a name which is a derogatory Pidgin word; actually the term "mbutuku" as noted above means "idiot" and the character's name is "Honourable Mbutuku". He makes Akwenoh speak Pidgin: she is the wife to the deceased parliamentarian and a housewife with no education. This same Akweno is spoken to in Pidgin by Ebbi, one of her former boyfriend who has just returned to the country after a long stay in Europe 
and by Honourable Malingo, the Parliamentary Group Leader. Old women like Ma Eseke are referred to with Pidgin titles and they themselves usually speak in Pidgin. The driver of the hearse carrying Honourable Mbutuku's corpse speaks Pidgin.

In "Betrothal without libation", children address their mothers using Pidgin titles. Petit traders and bar owners speak with their customers in Pidgin and so do bus station touts; old people like Fointam's father are spoken to in Pidgin, and so are strangers. In "The lady with the beard" (see p. 24, p. 85), old women speak and are spoken to in Pidgin and so are strangers and rural people. The situation in "Beasts of no nation" is similar: grave diggers sing Pidgin songs and interact in Pidgin.

This finding is presented on Table 7 below:

Table 7.

Indexical information on people speaking Pidgin in the corpus

\begin{tabular}{|c|c|c|c|c|c|}
\hline Books & $\begin{array}{c}\text { The widow's } \\
\text { might }\end{array}$ & $\begin{array}{c}\text { Betrothal } \\
\text { without } \\
\text { libation }\end{array}$ & $\begin{array}{c}\text { The lady } \\
\text { with the } \\
\text { beard }\end{array}$ & $\begin{array}{c}\text { My bundle } \\
\text { of joy }\end{array}$ & $\begin{array}{l}\text { Beasts of } \\
\text { no nation }\end{array}$ \\
\hline $\begin{array}{l}\text { Characters } \\
\text { who speak } \\
\text { Pidgin }\end{array}$ & $\begin{array}{l}\text { - idiots } \\
\text { - uneducated } \\
\text { house wife } \\
\text { - old people } \\
\text {-driver }\end{array}$ & $\begin{array}{l}\text { - old people } \\
\text { - petit } \\
\text { traders } \\
\text { - bar owners } \\
\text { and } \\
\text { customers } \\
\text { - bus station } \\
\text { touts } \\
\text { strangers }\end{array}$ & $\begin{array}{l}\text { - old people } \\
\text { - strangers } \\
\text { - rural } \\
\text { people }\end{array}$ & $\begin{array}{l}\text { - old people } \\
\text { - herbalists } \\
\text { - servants }\end{array}$ & $\begin{array}{l}\text { - grave } \\
\text { diggers }\end{array}$ \\
\hline
\end{tabular}

In short, characters who speak Pidgin or are spoken to in Pidgin in the corpus are generally old people, housewives, drivers, petit traders, bar owners and their customers, rural people, herbalists who handle traditional drugs and grave diggers. These people have in common the fact that in Cameroon they are generally uneducated and are hardly looked up to in the society. As can be inferred, this finding answers the second research question underlying this investigation. 
Jean Paul KOUEGA, Mildred ASEH

\section{Social Factors Underlying the Switch from English to Pidgin in the Corpus}

Gumperz's (1982) "contextualization cue" and Myers-Scotton's (1993) markedness theory outline some of the reasons that underlie the switch from one language to another in bilingual and multilingual communities. In the corpus under study, seven factors seem to determine the switches from English, the unmarked linguistic choice, to Pidgin, the marked linguistic choice. These are: the need to show solidarity, to mark respect, to criticise or be rude, to entertain, to name people, places and objects, to use a common language, and to express formality. These factors, which all contribute to the development of multilingualism in literature on the one hand and in society on the other, are considered in turn.

To show solidarity or compassion, characters in writings and people in the community switch to Pidgin. For example, in "The widow's might", when Honourable Malingo, the Parliamentary Group leader, approached the deceased's wife at the wake keeping ceremony, he said in Pidgin: "Madam, ashia". As was noted above, "ashia" is an expression of compassion addressed to someone who is in pains. Respect is usually indicated by the use of Pidgin titles like "ma", "pa", "mama", "papa" whenever a young speaker is to refer to an older person. To criticise government officials in "Beasts of no nation", grave diggers use Pidgin, the language they master. When characters are in good mood like Kechen in "My bundle of joy", they tune in Pidgin songs which they sing at the top of their voice and dance as well. Occasionally, the need may arise to name characters in a jocular way in which case writers tend to turn to Pidgin. This is the case with the name Honourable Mbutuku, a Pidgin word which means "idiot" as was noted above. Similarly by referring to a low class people's meal made up of cassava paste, okra soup and dried herring by the Pidgin name of this meal i.e. "garri, okro soup and bonga", the writer clearly shows how poor a potentially rich character has become:

Thank God, she never set foot in that farm to incur rashes. Their daily meal was garri and okro soup with bonga. The promises of a youthful husband who was a civil servant could not be attained. (Nkengasong, 2006, p. 37) 
In the contexts where the works in the corpus are set, a stranger generally communicates in Pidgin first and in case Pidgin fails, then English is used. This explains the use of direct speech in this extract: "My pikin come helep me" i.e. "My child, can you give me a helping hand!":

Presently, Ntube saw a woman in overflowing Igbo gowns dragging two huge bags toward the hut. "My pikin, come helep me," the stranger entreated. Ntube ran to her and helped tug one of the bags into the hut. (Alobwed'Epie, 2005, p. 32)

Finally, to vary the degree of formality of an interaction, writers usually switch from English, the formal language to Pidgin, the informal language. A high ranking person or an equal is spoken to in English, while a low-ranking person is addressed in Pidgin. In "My bundle of joy" for example, Kechen addresses Mallam, the herbalist in Pidgin. In "Betrothal without libation", Foimtam addresses the bar tender in Pidgin and converses with his colleague Sama in English. This confirms the fact that English and Pidgin are in a diglossic situation in Cameroon, with English being the high language and Pidgin, the low language.

In short, Pidgin is used in the corpus to play various stylistic functions including signalling solidarity and formality. This finding therefore answers the third research question guiding this work.

\section{Conclusion}

This study has dealt with Pidgin in creative works in English in Cameroon. The works examined are two novels and three plays all published between 2000 and 2006, and the frame adopted draws from Gumperz's contextualisation cue and Myers-Scotton's markedness theory. The research, which was guided by three key questions, revealed amongst other things that Pidgin in the corpus takes the form of individual lexemes like nyongo (witchcraft) and relatively short utterances like Bringam quick! (Bring it fast!). The characters who speak it or are spoken to in it are generally low-ranking people, rural dwellers, illiterates and other people who are hardly looked up to in the Cameroonian society. Finally, the use of Pidgin is found to help writers to realise some stylistic effects like solidarity and formality which the English language might not be able to convey in a meaningful way. 
Most importantly, creative writers try to capture in their works the features of Pidgin observed in the Cameroonian society. Similar studies need to be conducted elsewhere so as to shed light on how competent writers manipulate two languages operating in a somewhat diglossic way like English and Pidgin in Cameroon.

\section{References}

\section{The corpus}

Alobwed'Epie, C. (2005). The lady with the beard. Yaounde: Editions CLE.

Bate Besong (2003). Beasts of no nation in three plays. Yaounde: Editions CLE.

Bole Butake (2005). Betrothal without libation. Yaounde: Editions CLE.

Nkengasong, N. J. (2006). The widow's might. Yaounde: Editions CLE.

Tanyi-Tang, A. (2000). My bundle of joy. In Ewa and Other Plays (pp. 40-63).

Yaounde: Editions CLE.

\section{Works}

Abdkr, Abbo Yerima, (2000). The teaching of Arabic through fulfulde in North Cameroon from 1960 to 1984 (DEA dissertation). University of King Faysal, Sudan.

Ambanassom, S. (2008). Fifty years of anglophone Cameroon literature. Retrieved from http://www.eduartinc.org or http://www.eduartawards.org.

Biloa, E. (1999). Structure phrastique du Camfranglais: Etat de la question. [Camfranglais Sentence Structure: The State of the Question]. In G. Echu \& A. W. Grundstrom (Eds.) Official Bilingualism and Linguistic Communication in Cameroon (pp. 147-176). New York: Peter Lang.

Biloa, E. (2003). La langue française au Cameroun [The French Language in Cameroon] Bern: Peter Lang.

Dieu, M. \& Renaud, P. (1983). L'Atlas linguistique du Cameroun. [The linguistic atlas of Cameroon] Paris: CERDOTOLA - Agence de Coopération Culturelle et Technique [Cultural and Technical Cooperation Agency].

Echu, G. (2001). Le camfranglais: L'aventure de l'anglais en contexte multilingue camerounais. [Camfranglais: The adventure of English in the Multilingual Context of Cameroon] (pp. 207-221). Ecritures VIII: L'Aventure. 
Ethnologue (2005). Cameroon. Retrieved from http://www.ethnologue.com/ show_country.asp?name= Cameroon.

Fasse-Mbouya, I. (2000). English and French Loans in Ngiemboon (Unpublished MA dissertation). University of Yaounde I.

Fouda, H. (1991). An analysis of some European loans in Ewondo (Unpublished DIPES II Dissertation). Higher Teacher Training School (ENS), Yaounde, Cameroon.

Gumperz, J. (1982). Discourse strategies. Cambridge: Cambridge University Press.

Kachin, B., (1990). The phonological adaptation of English loan words in Medumba (Unpublished DIPES II Dissertation). Higher Teacher Training School (ENS), Yaounde, Cameroon.

Koenig, E. L., (1983). A sociolinguistic profile of urban centers. In E. L. Koenig, E. Chia \& J. Povey (Eds.), A Sociolinguistic Profile of Urban Centers in Cameroon (pp. 33-54). Los Angeles: Crossroads Press.

Kouega, J. P. (2001). Pidgin facing death in Cameroon. Terralingua. Retrieved from: http://www.terralingua.org/DiscPapers/DiscPaper17.html.

Kouega, J. P. (2003a). Camfranglais: A novel slang in Cameroon schools. English Today, 19(2), 23-29.

Kouega, J. P. (2003b). Word formative processes in Camfranglais. World Englishes, 22(4), 511-538.

Kouega, J. P. (2007a). The language situation in Cameroon. Current Issues in Language Planning (CILP), 1-94.

Kouega, J. P. (2007b). A dictionary of Cameroon English usage. Berne. Germany: Peter Lang.

Kouega, J. P. (2013). Camfranglais: A glossary of common words, phrases and usages. Lincom. Muenchen, Germany: Lincom Europa.

Kouega, J. P. (2015). A dictionary of Cameroon Pidgin English usage. Pronunciation, grammar and vocabulary. Muenchen, Germany: Lincom Europa.

Lewis, M. P., Simons, G. F. \& Fennig, C. D. (Eds.) (2014). Ethnologue: Languages of the World, 17th edn. Dallas, Texas: SIL International. Retrieved from http://www.ethnologue.com. 
Mbangwana, P. N. (1983). The scope and role of Pidgin English in Cameroon. In E. L. Koenig, E. Chia \& J. Povey (Eds.). (1983). A Sociolinguistic Profile of Urban Centers in Cameroon (pp. 79-92). Los Angeles: Crossroads Press.

Myers-Scotton, C. (1993). Common and uncommon ground: Social and structural factors in code-switching. Language in Society, 22, 475-503.

Njoya, M. (1988). French and Pidgin English in Shy Pemen (Unpublished DIPES II Dissertation). Higher Teacher Training School (ENS), Yaounde, Cameroon.

Todd, L. (1982). Varieties of English around the World T1: Cameroon. Heidelberg: Julius Groos.

Todd, L. \& Hancock, I. (1986). International English usage. Beckenham: Groom Helm.

Ze Amvela, E. (1989). Reflexions on social implications of bilingualism. Epasa Moto: A Journal of Language and Culture. The University of Buea, 5(2), $16-34$.

\title{
Jean Paul Kouega
}

Jaundès I universitetas, Kamerūnas; jkouega@yahoo.co.uk

Mildred Aseh

Jaundès I universitetas, Kamerūnas; asehm@yahoo.fr

\section{PIDŽINO - MAIŠYTOS ANGLU KALBOS - VARTOJIMAS ANGLU KALBA PARAŠYTUOSE KŪRINIUOSE KAMERŪNE}

\begin{abstract}
Santrauka. Šiame darbe, kuriame tiriama kodu kaita ir kalbos pasirinkimas daugiakalbiuose kontekstuose, aprašoma maišyta vietinè ir anglu kalba - pidžinas angliškuose kūriniuose Kamerūne, ypatinga demesi skiriant šios kalbos formoms, randamoms kūriniuose, ir veikejju tipams, kurie kalba tokia kalba, bei jos funkcijoms kūriniuose. Tyrimo objektas - dvi pjesès ir trys romanai, išleisti patyrusiu, puikiai anglu kalba mokančiu rašytoju, tačiau savo veikejjus verčiančiu kalbèti pidžinu. Tyrimas rodo, kad pidžino atvejus šioje duomenu bazeje sudaro pavienès leksemos, pavyzdžiui, salaka (aukojami gèrimai, auka), arba salyginai trumpos frazès, kaip This sun fit kill man (Saulè tokia kaitri, kad gali ką nors pražudyti.). Veikèjai, kalbantys maišyta kalba, paprastai vaizduojami kaip žemos klasės kaimo žmonès, neraštingi asmenys ir tokie, i kuriuos kamerūniečiai paprastai nesilygiuoja. Be to, pidžinas rašytojams padeda atskleisti kai kuriuos stiliaus bruožus, pavyzdžiui, formalumo lygio pokyčius, kai anglu kalba vartojama kreipiantis i viršesni asmeni, o pidžinu - kalbant su menkesniais už save. Svarbiausia, kad savo darbuose rašytojai atspindi Kamerūno visuomenę, taip galbūt formaliai stiprindami savo skaitytoju daugiakalbystès kompetencija.
\end{abstract}

Raktažodžiai: Kamerūno pidžinas - maišyta anglu kalba, kūrybiniai darbai, kodu kaita, požiūris, kalbos pasirinkimas. 